\title{
GEODYNAMICS OF THE TAIMYR PENINSULA FROM GEOPHYSICAL DATA
}

\author{
D. G. Kushnir
}

\author{
JSC Taimyrgeofizika (Group of Companies JSC Bashneftegeofizika), Dudinka, Russia
}

\begin{abstract}
Recently, a unique geophysical polygon has been created on the Taimyr Peninsula and the adjacent territories. Its densely spaced set of seismic and electric prospecting profiles makes it possible to investigate the structure of the continental lithosphere to the depths of 50-60 km (Fig. 1). The sedimentary cover and the deep horizons of the crust and upper mantle are studied in detail to discover new facts in the history of the geological development of the northern Siberian platform. The contrasting anomalies recorded at the lower crust levels give evidence of considerable changes in density and electrical conductivity, which coincide in plan with the most significant geological structures in the northern regions of Central and West Siberia (Fig. 2). The relationships of the largest uplifts and troughs with the decomposition and compacting processes at the level of Moho are indicative of, on the one hand, the metamorphism occurring under the influence of asthenospheric fluids, and, on the other, the determining role of lithostatic pressure equalization in the formation of these structures. Thus, for the first time, the direct geophysical surveys have shown that the nature of tectonic processes is not limited to only simple horizontal movements of the cratons and associated deformation. Our data shows that the deep geological structure of the study area can be explained, in addition to collision, by the vertical stresses associated with the compaction/decompaction of the crust under the influence of the materials uplifted from the mantle and the lithostatic pressure equalization compensating for the density changes. The vertical tectonic movements are not unidirectional and periodically change their sign, as evidenced by the inversion nature of the largest structures of the sedimentary cover in the Taimyr Peninsula (Fig. 3). In the course of the geological development, the troughs are generally replaced by banks, and uplifts and ridges are involved in subduction, to varying degrees. According to the data obtained, such changes are determined by the differences in the depth levels of the large blocks of the lower crust and upper mantle. These variations seem to play a significant role on other continents; in that regard, their further studies will contribute to a better understanding of global geodynamics.
\end{abstract}

Key words: Taimyr Peninsula; geodynamics; tectonics; seismic prospecting; electrical exploration; gravitational anomaly; upper mantle; Earth's crust; Moho; Yenisei-Khatanga trough; Rassokha megalithic bank; Gulinsky massif of ultramafic rocks

For citation: Kushnir D.G., 2018. Geodynamics of the Taimyr Peninsula from geophysical data. Geodynamics \& Tectonophysics 9 (1), 81-92. doi:10.5800/GT-2018-9-1-0338.

Для цитирования: Кушнир Д.Г. Геодинамика полуострова Таймыр по геофизическим данным // Геодинамика и тектонофизика. 2018. T. 9. № 1. C. 81-92. doi:10.5800/GT-2018-9-1-0338. 


\title{
ГЕОДИНАМИКА ПОЛУОСТРОВА ТАЙМЫР ПО ГЕОФИЗИЧЕСКИМ ДАННЫМ
}

\author{
Д. Г. Кушнир \\ АO «Таймыргеофизика» (группа компаний АО «Башнефтегеофизика»), Дудинка, Россия
}

\begin{abstract}
Аннотация: В последние годы на полуострове Таймыр и в пределах прилегающих территорий создан уникальный геофизический полигон с высокой плотностью сейсморазведочных и электроразведочных профилей, позволяющий осветить строение континентальной литосферы до глубин 50-60 км (рис. 1). Высокая детальность изучения осадочного чехла, глубоких горизонтов земной коры и верхней мантии открывает новые факты истории геологического развития севера Сибирской платформы. В низах земной коры зафиксированы контрастные аномалии, которые свидетельствуют об обширных изменениях плотности и электропроводности, совпадающих в плане с наиболее значимыми геологическими структурами севера Центральной и Западной Сибири (рис. 2). Взаимосвязь крупнейших поднятий и прогибов с процессами разуплотнения и уплотнения на уровне раздела Мохоровичича свидетельствует, с одной стороны, о протекающем там под действием астеносферных флюидов метаморфизме, с другой - об определяющей роли литостатического выравнивания при формировании этих структур. Таким образом, впервые прямыми геофизическими наблюдениями установлено, что природа тектонических процессов не исчерпывается простыми горизонтальными перемещениями кратонов и связанными с ними деформациями. Согласно полученным данным, глубинное геологическое строение региона, помимо коллизий, объясняется вертикальными напряжениями, связанными с уплотнением или разуплотнением земной коры под воздействием поступающего из мантии вещества и литостатическим выравниванием, компенсирующим эти изменения плотности. Вертикальные тектонические движения не являются однонаправленными и периодически меняют свой знак, о чем свидетельствует инверсионный характер крупнейших структур осадочного чехла Таймыра (рис. 3). В ходе геологического развития на месте прогибов, как правило, образуются валы, а поднятия и гряды в той или иной степени захватываются опусканием. Такие изменения, согласно новым данным, определяются колебанием уровня залегания крупных блоков нижней коры и верхней мантии. Подобные колебательные движения, видимо, имеют большое значение и для других континентов, в связи с этим их дальнейшее изучение позволит глубже понять глобальную геодинамику в целом.
\end{abstract}

Ключевые слова: Таймырский полуостров; геодинамика; тектоника; сейсморазведка; электроразведка; гравитационная аномалия; верхняя мантия; земная кора; граница Мохоровичича; Енисей-Хатангский прогиб; Рассохинский мегавал; Гулинский массив ультрамафитов

\section{1. ВВЕДЕНИЕ}

С начала 2000-х годов на Таймыре реализуется широкомасштабный план по выполнению региональных нефтегазопоисковых исследований на базе геофизического комплекса, основу которого составляют сейсморазведка методом общей глубинной точки (МОГТ) и электроразведка методами магнитотеллурического зондирования (МТЗ) и зондирования становлением поля в ближней зоне (ЗСБ) [Kazais et al., 2007; Kushnir, 2013]. С учетом законченных в 2017 г. работ на доступной для стандартной сейсморазведки территории полуострова завершена первая стадия регионального изучения (рис. 1), реализованная по редкой сети маршрутов (30×30 - 60×60 км). В ближайшие годы планируется завершить и вторую стадию исследований, нацеленную непосредственно на лицензирование и осуществляемую по сети $5 \times 5-20 \times 20$ км. Полученный на сегодняшний день не имеющий аналогов информационный полигон уже включает порядка 30 тыс. км сейсморазведочных и электроразведочных профилей, освещающих разрез земной коры на всю ее мощность, до уровня 50-60 км, в полосе протяженностью около 1500 км и шириной от 300 до 700 км.

Наряду с детальными данными по целевым продуктивным уровням геологического разреза, появилась уникальная информация по глубоким горизонтам земной коры, строение которых до сих пор никогда не освещалось с такой высокой детальностью на столь значительной площади. Благодаря сочетанию глубинности исследований, плотности сети маршрутов, качеству полученных материалов и комплексированию геофизических методов, впервые в мировой практике изучения континентальной литосферы создана столь обширная и надежная фактическая база геофизических данных для детального прогноза ее строения и обоснованных геодинамических выводов. Это в 


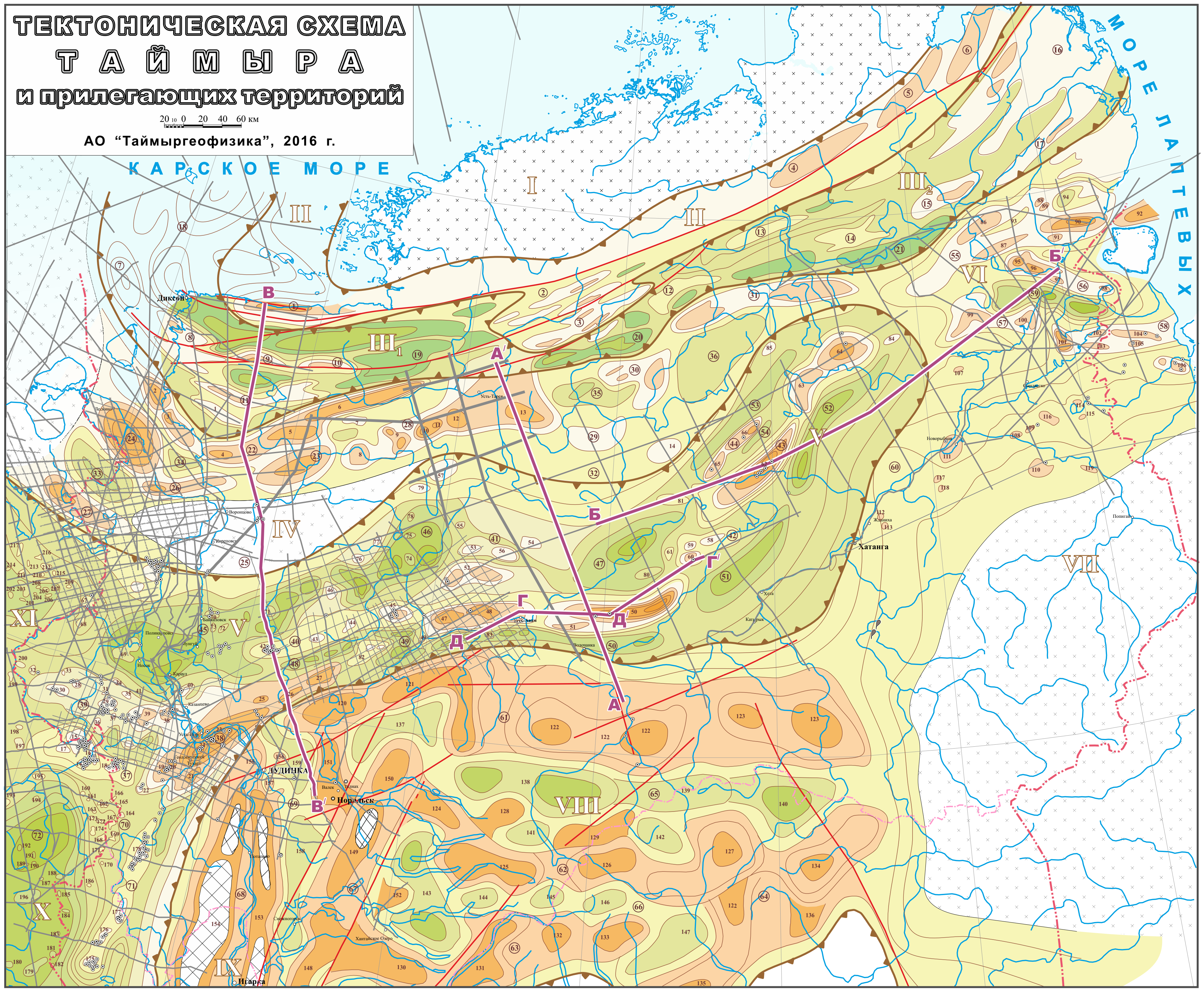

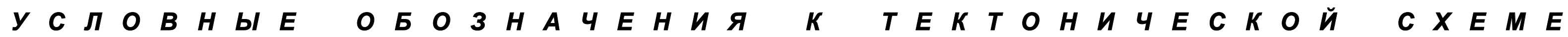
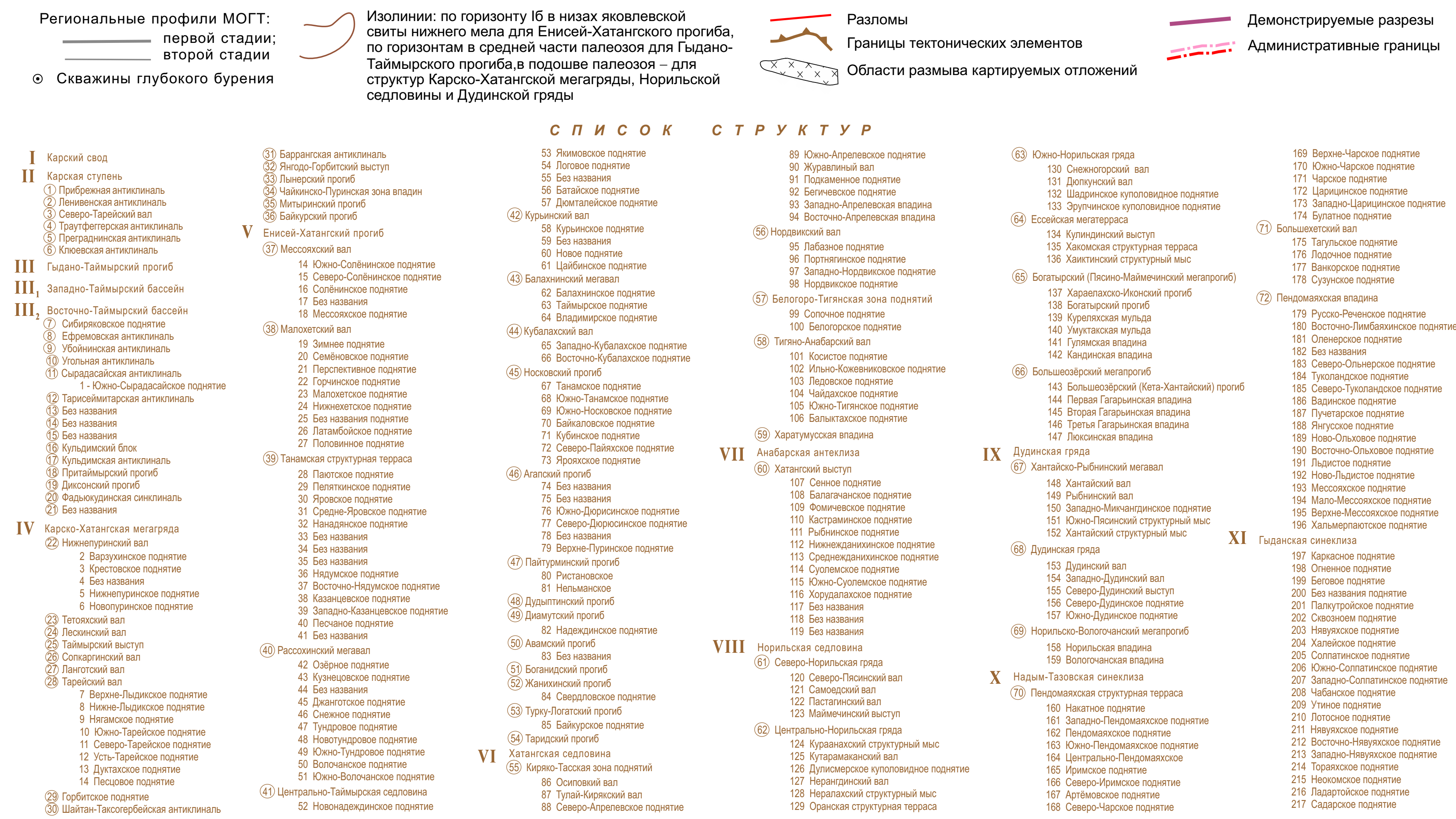
сочетании с не менее надежным картированием всех наиболее значимых особенностей седиментации, в той или иной степени запечатленных в осадочном чехле, открывает возможность аргументированного восстановления истории геологического развития важнейших геоструктур региона.

До 1990-2000-х годов геосинклинальное происхождение большинства структурных форм Таймыра не подвергалось сомнению. А.Д. Архангельский, И.Б. Атласов, И.В. Боголепов, В.А. Вакор, В.Э. Волк, Б.Х. Елизаров, Т.П. Кочетков, П.К. Куликов, И.М. Мигай, А.В. Пейве, Ю.Е. Погребицкий, Ю.М. Пущаровский, Н.Н. Ростовцев, В.К. Соколов, Д.С. Сороков, Д.Б. Тальвирский, Н.Н. Урванцев, А.Л. Яншин и другие исследователи считали, что Таймырская складчатая система принадлежит к эпикратонным геосинклиналям Сибири и была заложена в эпоху герцинской складчатости в результате интенсивного горообразования в смежной Тихоокеанской геосинклинали. В этом контексте предполагалось, что с конца триасового периода Таймырская складчатость и Енисей-Хатангский прогиб начали развиваться совершенно разными, но связанными друг с другом путями: орогенез Горного Таймыра компенсировался перикратонным опусканием ЕнисейХатангского прогиба, заполнявшегося продуктами размыва Таймырской и Среднесибирской суши [Glagolev et al., 1994].

С 1990-2000-х годов, благодаря развитию палеомагнитных исследований и систем глобального геопозиционирования, применительно к Таймыру были доказаны основные положения тектоники плит. Исследования показали, что становление глубинной геологии Таймырского полуострова с конца пермского периода проходило в перманентных условиях субмеридионального сжатия, связанных с коллизией Карского и Сибирского кратонов, которая соответствующим образом проявилась в палеомагнитных данных [Vernikovsky et al., 2009; Metelkin et al., 2000, 2012], а также подтверждается высокоамплитудными надвигами и обдукцией покровов на континент [Vernikovsky, 1996]. С этого времени происхождение всех таймырских структур стало трактоваться исходя из примата коллизионных процессов.

В этой связи формирование занимающих большую часть площади полуострова юрско-меловых депрессий с точки зрения тектоники плит объясняется как результат рифтогенеза, и большинство специалистов сегодня относит формирование Енисей-Хатангского прогиба к следствиям растяжения, проявившегося в опускании по системе разломов крупных тектонических блоков, сопровождающихся деструкцией земной коры и верхней мантии. Предполагается, что на рубеже перми и триаса в Западной Сибири образовалась субмеридиональ- ная система грабеновых структур, ответвлением которой считается осевой грабен Енисей-Хатангского желоба, образовавшийся под действием тангенциальных напряжений [Aplonov, 1989; Bazhenov, Mossakovsky, 1986; Girshgorn et al., 1987; Metelkin et al., 2012; Surkov, 1998; Khain, Lomize, 1995; Khain, 2001; u $\partial p$.].

\section{2. НОВЫЕ ДАННЫЕ}

Основные факты, установленные на Таймырском полигоне по итогам региональных нефтегазопоисковых работ нового этапа и маркирующие важнейшие этапы геологического развития этой крупнейшей до сей поры почти не изученной части Евразийского континента, сводятся к следующему.

1. В низах земной коры, в основании мезозойских депрессий, фиксируется крупная аномальная зона, выражающаяся повышением скорости распространения упругих колебаний (до 6.9-7.4 км/с по продольным волнам и до 4.2 км/с по поперечным [Kostyuchenko, 2000; Surkov et al., 1987]), погружением сейсмической границы M, возникновением выше нее границы КМ (рис. 2). В разрезе с этой аномалией совпадает понижение удельного электрического сопротивления, а в плане - гравитационный максимум, который проявляется, если убрать из наблюденного поля силы тяжести влияние осадочного чехла и поверхности кристаллического фундамента [Kazais, Yagantsev, 1971; Kushnir, 2016]. Также ее положению соответствует максимум геотермического градиента [Smirnov, 1980]. Данная аномальная зона тянется через Таймыр и Гыдан более чем на 1500 км при ширине от 300 до 700 км, расширяясь в направлении Западной Сибири.

2. На фоне рассмотренной аномальной зоны под Малохетским, Рассохинским и Балахнинским мегавалами наблюдается максимум удельного электрического сопротивления, охватывающий почти весь изученный интервал разреза земной коры (рис. 2). Он совпадает с интенсивным гравитационным максимумом, а также с прекращением прослеживания отражающих площадок на уровне раздела Мохоровичича и в нижней коре. Данные аномалии при ширине до 200 км тянутся на сотни километров и в юго-восточной части полуострова объединяются с аналогичными аномалиями Гулинского массива ультрамафитов, что может служить признаком единства и аномалеобразующего объекта.

3. С положением мегавалов совпадают максимальные мощности палеозойских и триасовых толщ (во многих случаях и верхнерифейских рис. 2,3 ), то есть, по-видимому, они унаследовали положение доюрского депоцентра прогибания и 


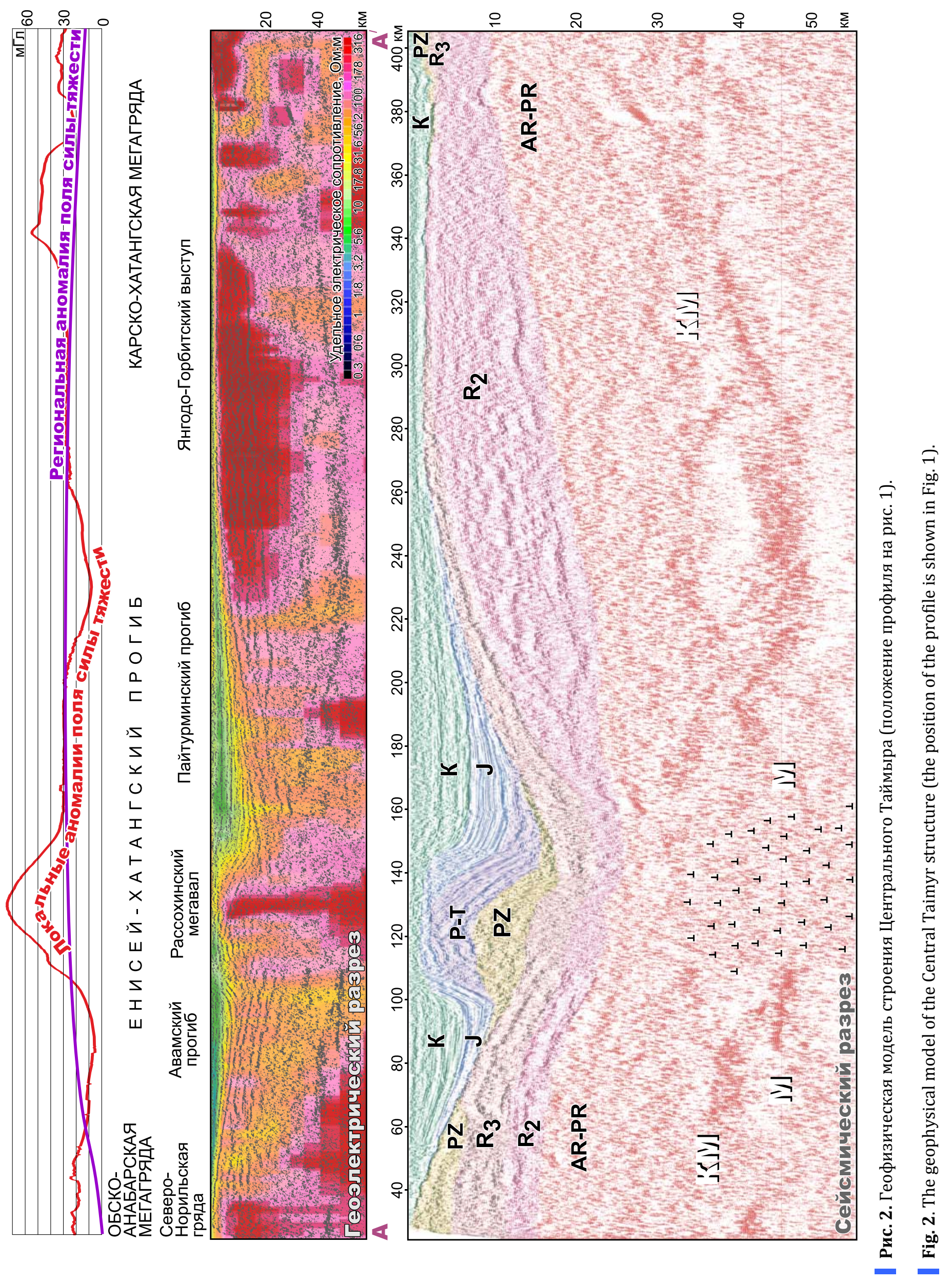




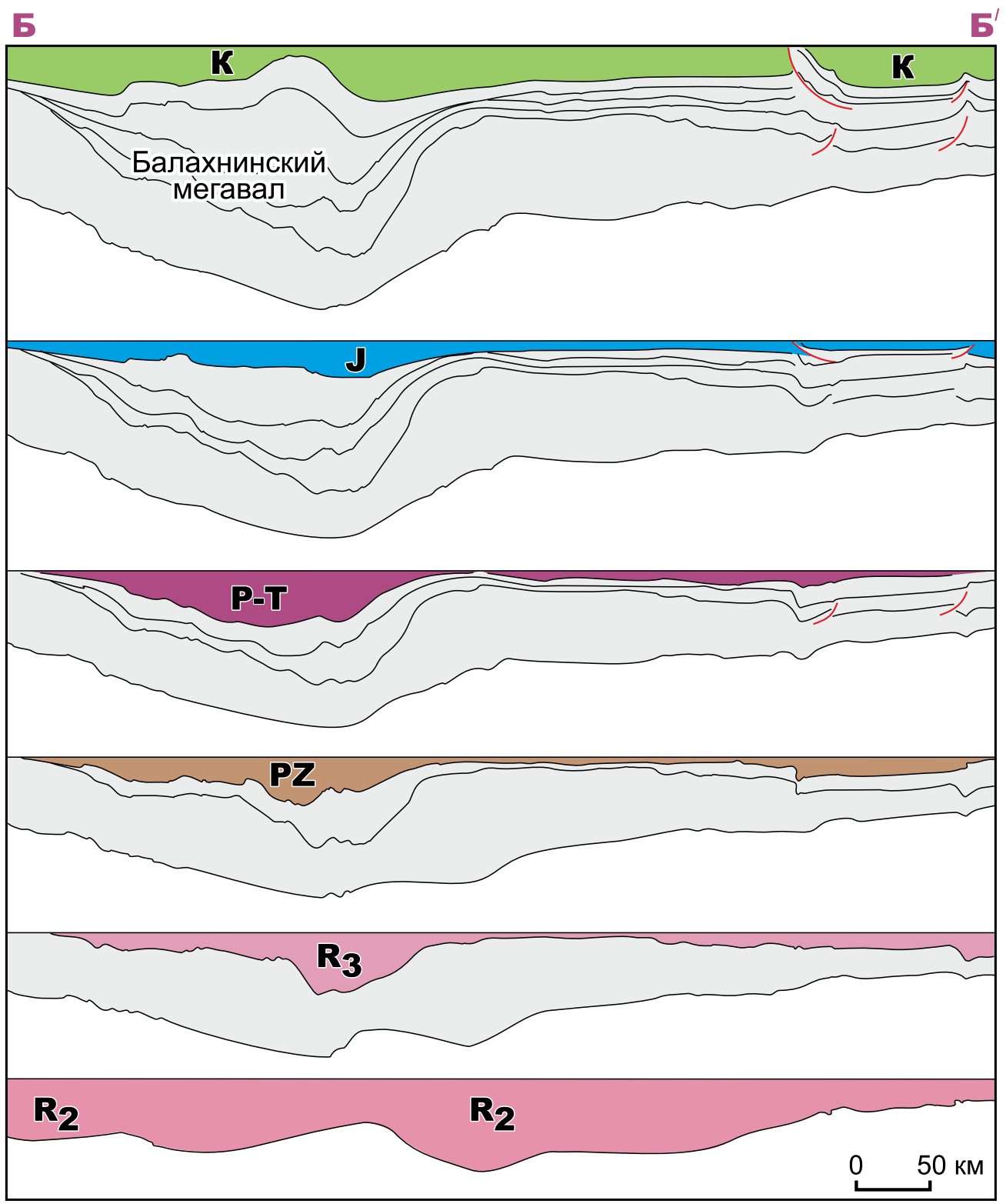

Рис. 3. Палеореконструкции Восточного Таймыра (положение профиля на рис. 1).

I Fig. 3. The East Taimyr paleoreconstructions (the position of the profile is shown in Fig. 1).

представляют собой результат его полной инверсии. Одновременно с ростом валов сформировались новые депоцентры прогибания, расположенные за пределами появляющихся в осевой части депрессии поднятий.

4. Енисей-Хатангский прогиб в целом предстает как унаследованная структура, которая, начиная со времени своего заложения в позднем рифее - раннем палеозое, непрерывно расширяется. Скорость расширения изначально была практически постоянной, но к началу мелового периода она заметно возросла, и охваченная прогибанием территория значительно увеличилась, местами даже удвоилась (см. рис. 2; рис. 4). В момент резкого увеличения скорости расширения депрессии возрастает и ско- рость ее погружения, что соответствующим образом отражается на характере седиментации. Накопление осадков в прогибах почти повсеместно становится некомпенсированным, и отлагаются клиноформные толщи.

5. Примерно к этому же моменту приурочено катастрофически быстрое воздымание Рассохинского и Балахнинского мегавалов. Их рост обгонял даже ускоренное погружение на периферии, где мощность клиноформных толщ заполнения редко превышает 1.5 км, в то время как в своде валов на рубеже юры и мела местами было размыто более 3 км осадков (рис. 5). Следовательно, в этот период на фоне широкого наступления моря и некомпенсированного погружения депрессий в пределах 

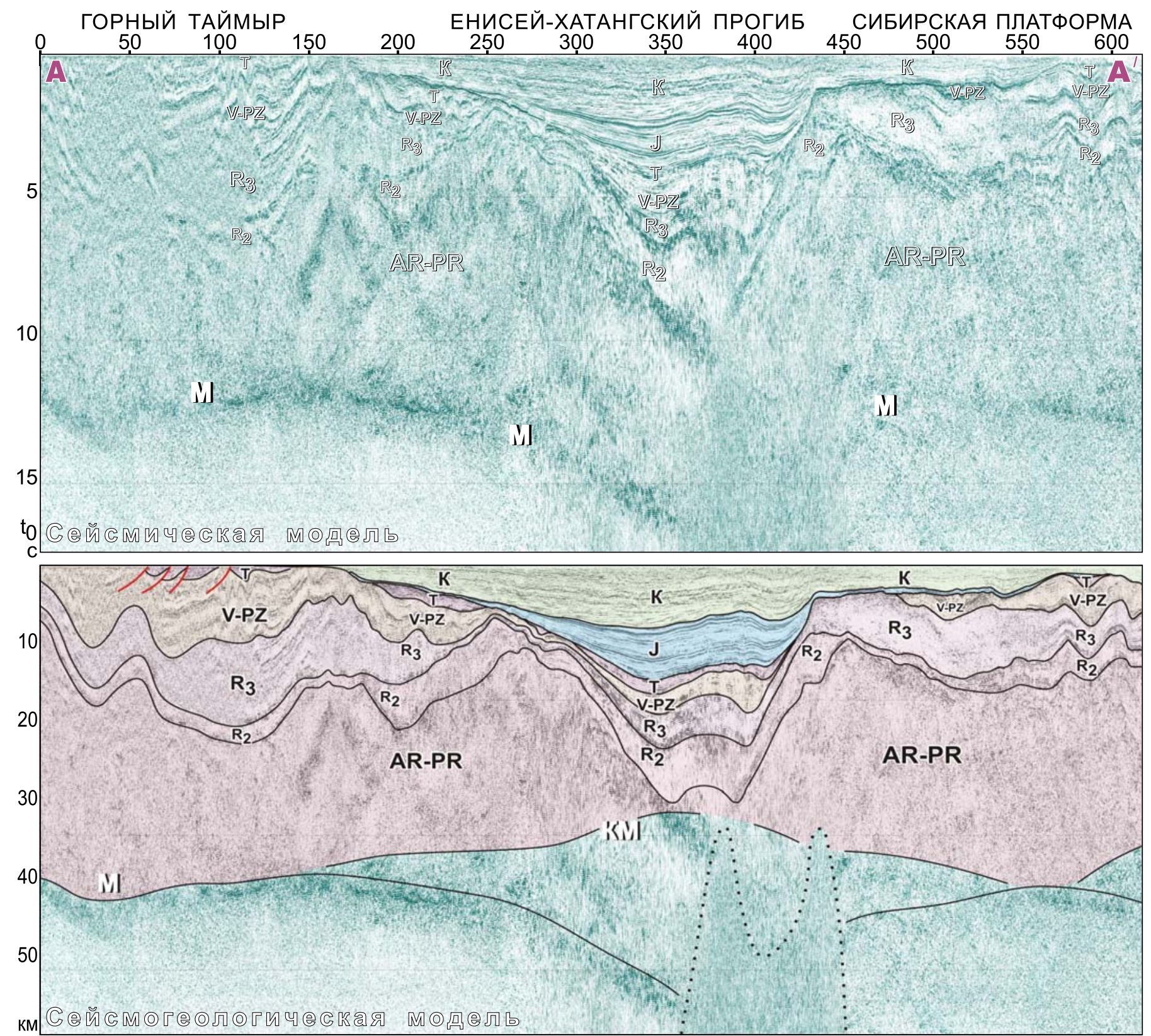

Рис. 4. Модель глубинного геологического строения Приенисейской полосы Таймыра (положение маршрута на рис. 1).

Fig. 4. The model showing the deep geological structure of the Near-Yenisei band in the Taimyr Peninsula (the position of the route is shown in Fig. 1).

Центрального Таймыра доминировал растущий горный хребет.

6. Рост валов в центре полуострова сопровождался синхронными надвиговыми процессами в их сводовой части, где аллохтон размывался и служил источником сноса осадков вплоть до середины мела, о чем свидетельствуют расходящиеся сейсмофации в верхнеюрских и особенно нижнемеловых уровнях на его фронте (рис. 6).

7. Несмотря на активные тектонические перестроения в домезозойском интервале разреза практически повсеместно прослеживаются относительно хорошо сохранившиеся палеозойские и верхнерифейские осадки, слагающие систему складок разного порядка с амплитудой до 5 км и более (рис. 7). На этом фоне дизъюнктивная тектоника как региональный фактор себя не проявляет, за исключением развитых в верхних слоях осадочного разреза дизъюнктивно-пликативных надвиговых структур, где амплитуда смещений аллохтона достигает первых десятков километров. 


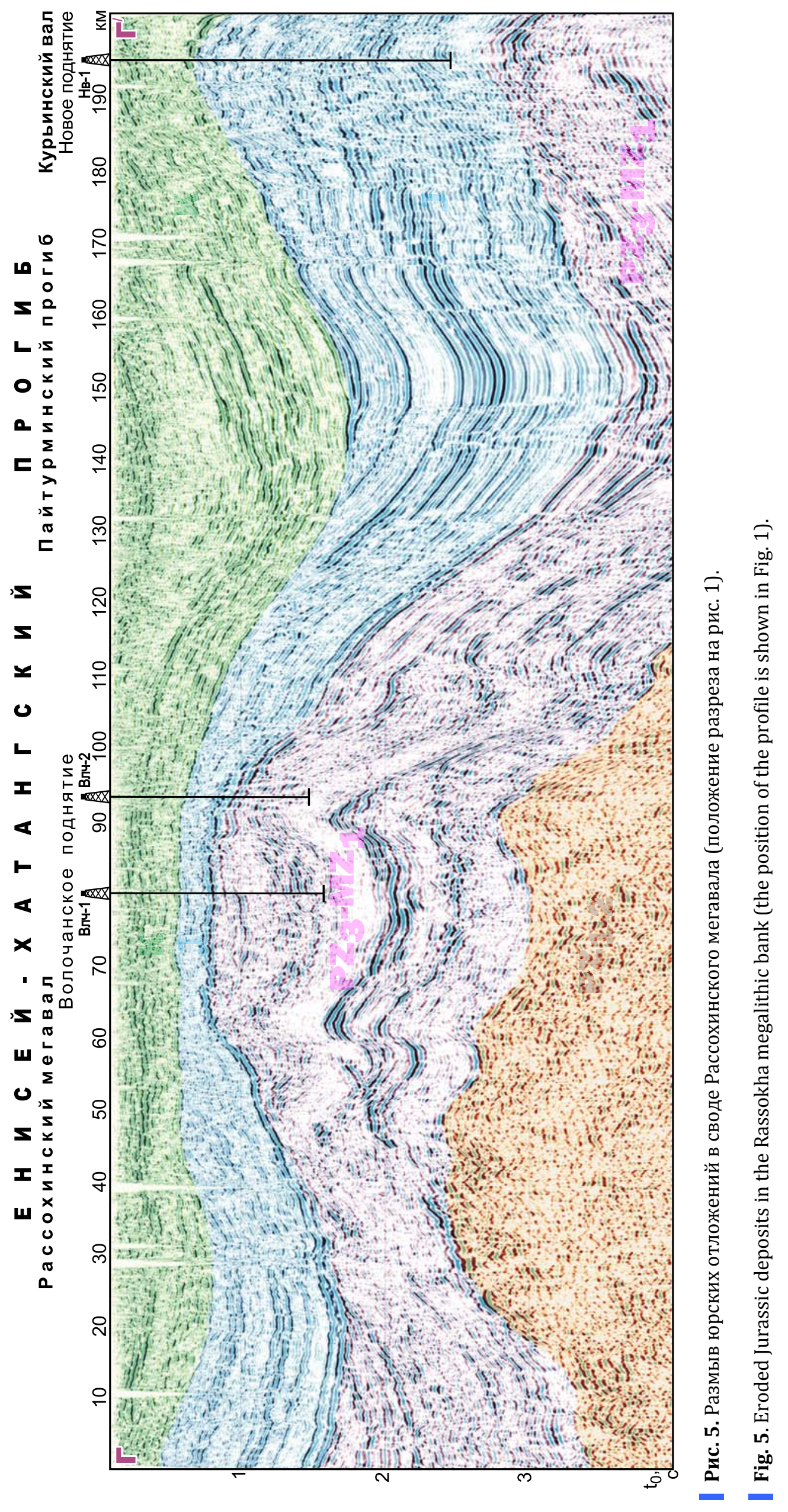




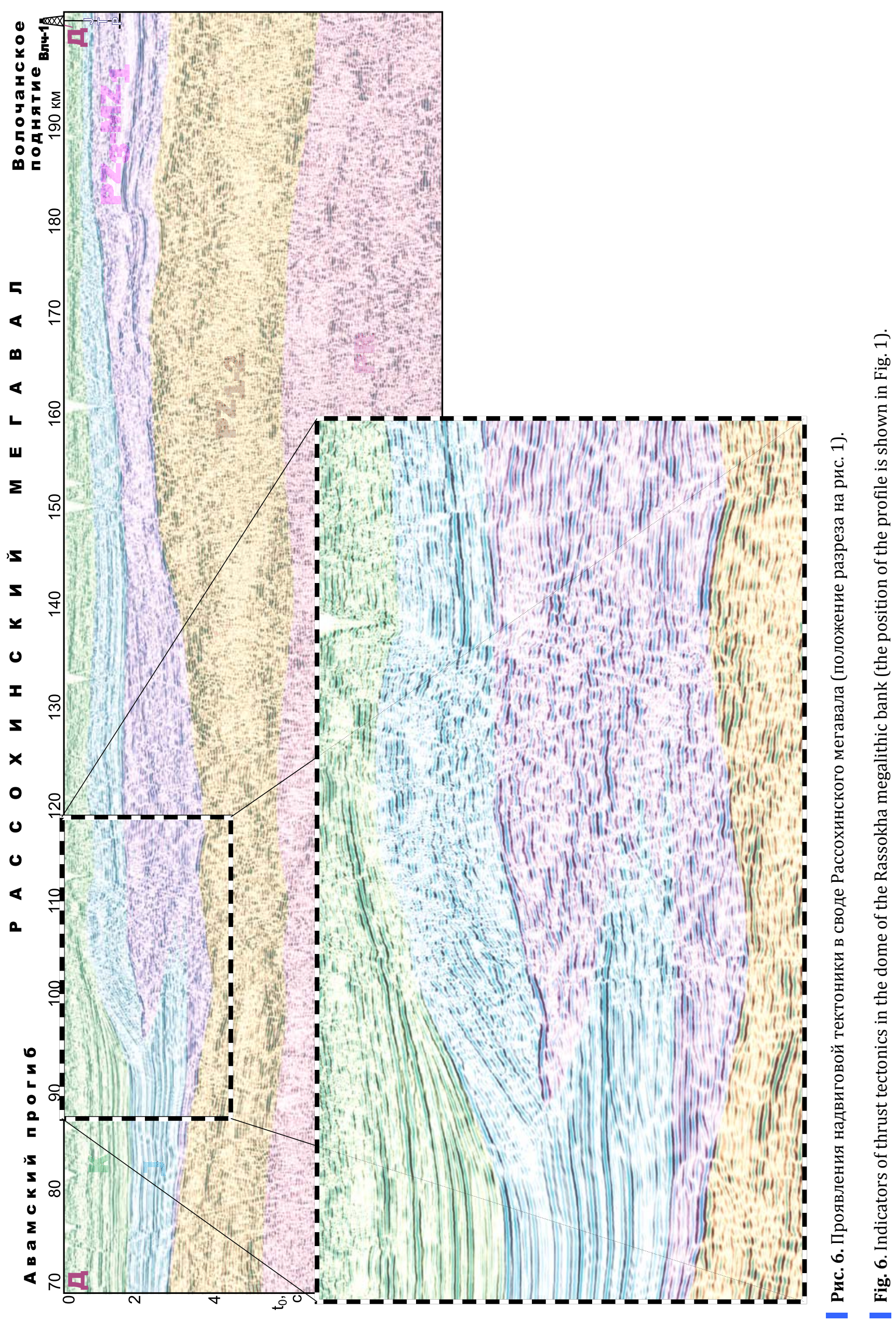




\section{3. ОБСУЖДЕНИЕ}

В свете изложенного приходится сделать вывод, что одновременное стремительное, не компенсированное накоплением осадков погружение и значительное расширение надпорядковой депрессии, сопровождающееся еще более быстрым ростом поднятия первого порядка в ее центре с надвиганием в своде, невозможно обосновать каким-либо растяжением. Не отрицая становление региона в условиях сжатия, связанного с коллизией Карской плиты и Сибирского континента, приходится констатировать, что все выявленные особенности строения Енисей-Хатангского прогиба никак не могут быть объяснены только с точки зрения его рифтогенного происхождения, тем более что в депрессиях севера Центральной и Западной Сибири повсеместно зафиксирована сохранность рифейско-палеозойского и триасового осадочного разреза, который должен был быть разрушен при образовании рифта.

Исключительно высокую по своей скорости и амплитуде инверсию движений в осевой части прогиба при одновременном расширении и ускорении прогибания на периферии депрессии (в неизменных коллизионных условиях и при отсутствии следов регионального растяжения) гораздо более естественно считать следствием глубинных мантийных факторов. В то же время горизонтальное сжатие также имело большое значение: оно обусловило развитие надвиговых систем, во многом определяющих современную геологию полуострова. Из этого следует, что крупнейшие тектонические структуры Таймыра появились в результате воздействия более сложной суперпозиции сил и напряжений, нежели считалось ранее.

Аномалеобразующий объект в низах земной коры, практически повторяющий в плане положение юрско-меловых депрессий и контрастно отражающийся на сейсмических и геоэлектрических разрезах, в гравитационном и тепловом полях, тянется на сотни километров. Появление объекта таких масштабов иначе как метаморфическими изменениями объяснить крайне сложно. При этом относительно пониженное его сопротивление (более характерное для частично расплавленной верхней мантии) и не столь значительная аномалия в поле силы тяжести могут свидетельствовать о меньшей консолидации, по сравнению с гипербазитовым телом в основании системы мегавалов (см. рис. 2): гипербазиты, благодаря глубокому проникновению метаморфических изменений, вызванных их внедрением, создают геоэлектрическую и гравитационную аномалии максимальной интенсивности.

Судя по всему, на начальном этапе в результате метаморфизма в нижней части земной коры сфор- мировались крупные тела повышенной плотности, что привело к относительно быстрому ее опусканию, направленному на достижение литостатического равновесия и сопровождающемуся возникновением региональных осадочных бассейнов.

Метаморфический механизм, который мог спровоцировать подобные литологические изменения, известен уже много лет и неоднократно рассматривался на примере становления депрессий Западной Сибири и других осадочных бассейнов [Artyushkov, 1979, 1993, 2003, 2010, 2012; Artyushkov, Chekhovich, 2014; Peskovsky, 1992]. По сложившимся представлениям, такие изменения состава являются следствием эклогитизации габбро в низах земной коры, что приводит к ее утяжелению и погружению.

Эклогитизация началась в позднем триасе, вероятно, в связи с развитием системы высокоамплитудных палеозойско-триасовых складок, нарушивших литологическое и термобарическое равновесие в основании земной коры, куда инициировалось проникновение сначала мантийных флюидов, а затем все больших объемов аномального по своим термоплотностным характеристикам мантийного вещества. Таким образом, появилась своего рода ловушка, которая по мере поступления в нее аномальной мантии постоянно расширялась, с одной стороны вовлекая в опускание все новые и новые территории, прилегающие к депрессии, с другой - все более раскрываясь для свежих астеносферных внедрений.

В позднеюрскую эпоху в наиболее измененной части земной коры, совпадающей с депоцентрами доюрского прогибания, начались внедрения гипербазитов, которые привели к инверсии движений и росту поднятий, сопоставимых по амплитуде с мощностью интрузивных тел на глубине. В области сочленения прогиба с Анабарской антеклизой по тектонически ослабленным зонам эти интрузии имели наибольшее проникновение и некоторые из них дошли до дневной поверхности (как, например, Гулинский массив).

Внедрение гипербазитов стало причиной обширных метаморфических изменений, охвативших в той или иной степени весь разрез земной коры, и практически прекратило доступ для мантийного вещества в осевую часть прогиба. В результате этого было обеспечено добавочное поступление аномальной мантии в периферийные части желоба, за счет чего влияние метаморфизма там усилилось, а связанное с ним погружение ускорилось и расширилось, что обусловило боковой снос осадков и соответствующее клиноформное строение неокомских толщ, маркирующее максимальную скорость погружения. Мегавалы в ходе остывания ультраосновных интрузивов в низах земной коры также 


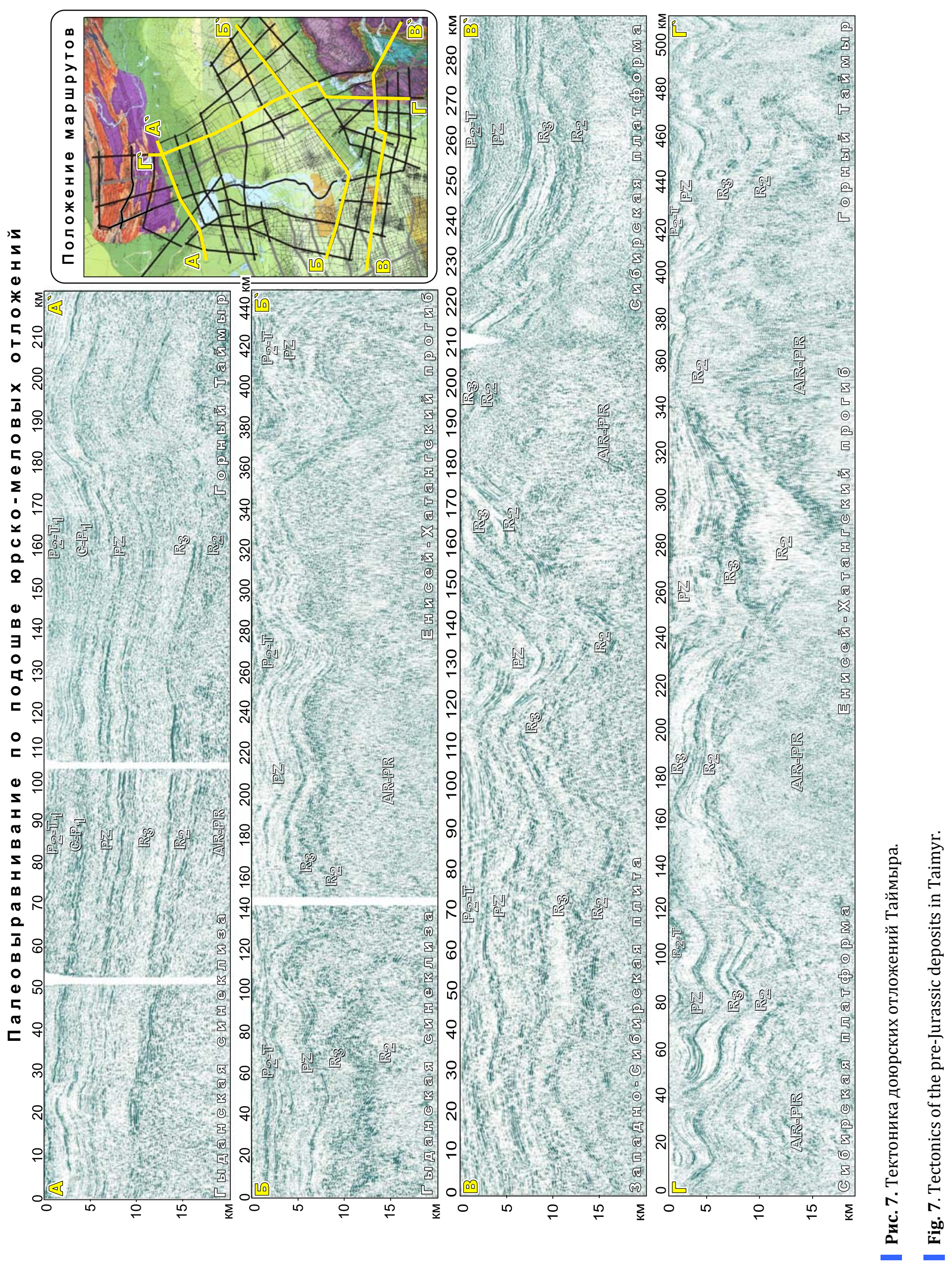


опускались, но скорость этого опускания была гораздо ниже, чем в депрессиях.

Протекание рассматриваемых процессов в условиях непрерывного регионального сжатия создает дополнительные предпосылки для роста амплитуды образующихся прогибов и валов, увеличивает их контрастность, контролирует простирание структур, приводит к широкому распространению надвиговых систем. Вследствие сжатия все основные тектонические элементы Таймырского полуострова выстраиваются вдоль фронта коллизии, при удалении от которого степень дислоцированности осадочного чехла закономерно снижается (см. рис. 1).

\section{4. ЗАКЛЮЧЕНИЕ}

Таким образом, впервые в практике геофизического изучения тектонические процессы фиксиру- ются как результат комплексного воздействия коллизионного сжатия и глубинных (мантийных) факторов, обусловивших изменения плотности в основании земной коры. Согласно полученным данным, формирование литосферы происходит гораздо более сложным образом, нежели предполагалось до сих пор, и не исчерпывается простым горизонтальным перемещением кратонов, их столкновением и связанными с этим деформациями. Это имеет значение для истории появления рассматриваемых крупнейших геоструктур Сибирского континента и немаловажно для других континентальных блоков, где глубокие прогибы до сих пор зачастую объясняются исключительно рифтогенезом. Следовательно, уникальные геофизические данные, полученные в последние годы на Таймыре и надежно аргументирующие редко используемые современной геодинамикой тектонические механизмы, открывают новые горизонты для ее развития.

\section{5. ЛИТЕРАTУРA / REFERENCES}

Aplonov S.V., 1989. Paleogeodynamics of Western Siberian plate. Sovetskaya Geologiya (Soviet Geology) (7), 27-37 (in Russian] [Аплонов С.В. Палеогеодинамика Западно-Сибирской плиты // Советская геология. 1989. № 7. C. 27-37].

Artyushkov E.V., 1979. Geodynamics. Nauka, Moscow, 328 p. (in Russian) [Артюшков E.В. Геодинамика. М.: Наука, 1979. 328 c.].

Artyushkov E.V., 1993. Physical Tectonics. Nauka, Moscow, 456 p. (in Russian] [Артюшков Е.В. Физическая тектоника. М.: Наука, 1993. 456 с.].

Artyushkov E.V., 2003. Abrupt continental lithosphere weakening as a precondition for fast and large-scale tectonic movements. Geotectonics 37 (2), 107-123.

Artyushkov E.V., 2010. Mechanism of formation of superdeep sedimentary basins: lithospheric stretching or eclogitization? Russian Geology and Geophysics 51 (12), 1304-1313. https://doi.org/10.1016/j.rgg.2010.11.002.

Artyushkov E.V., 2012. Neotectonic crustal uplifts as a consequence of mantle fluid infiltration into the lithosphere. Russian Geology and Geophysics 53 (6), 566-582. https://doi.org/10.1016/j.rgg.2012.04.005.

Artyushkov E.V., Chekhovich P.A., 2014. Neotectonic uplift of Early Precambrian cratons caused by metamorphism with rock expansion in the earth crust. Doklady Earth Sciences 458 (2), 1215-1219. https://doi.org/10.1134/S102 $8334 X 14100158$.

Bazhenov M.L., Mossakovsky A.A., 1986. Horizontal movement of the Siberian platform in the Triassic from paleomagnetic and geological data. Geotektonika (Geotectonics) (1), 59-69 (in Russian) [Баженов М.Л., Моссаковский А.А. Горизонтальные перемещения Сибирской платформы в триасе, по палеомагнитным и геологическим данным // Геотектоника. 1986. № 1. С. 59-69].

Girshgorn L.Sh., Kabalyk V.G., Sosedkov V.S., 1987. The Upper Paleozoic sediments of north-east of Western Siberia. Bulletin of Moscow Society of Naturalists, Geological section 62 (6), 12-18 (in Russian) [Гиршгорн Л.Ш., Кабалык В.Г., Соседков В.C. Верхнепалеозойские отложения северо-востока Западной Сибири // Бюллетень Московского общества испытателей природы, отдел геологический. 1987. Т. 62. Вып. 6. С. 12-18].

Glagolev P.L., Mazanov V.F., Mikhailova M.P., 1994. Geology and Hydrocarbon Potential of the Yenisei-Khatanga Trough. Institute of Geology and Mining of Fuels, Moscow, 118 p. (in Russian) [Глаголев П.Л., Мазанов В.Ф., Михайлова М.П. Геология и нефтегазоносность Енисей-Хатангского прогиба. М.: ИГиРГИ, 1994. 118 с.].

Kazais V.I., Mel'nik A.I., Kushnir D.G., 2007. Efficiency of the new stage of regional seismic surveys in Taimyr. In: Prospects for the development of the oil-and-gas production complex in the Krasnoyarsk Region. Proceedings of the Conference. Krasnoyarsk, p. 70-75 (in Russian) [Казаис В.И., Мельник А.И., Кушнир Д.Г. Эффективность нового этапа региональной сейсморазведки на Таймыре // Перспективы развития нефтегазодобывающего комплекса Красноярского края: Материалы конференции. Красноярск, 2007. С. 70-75].

Kazais V.I., Yagantsev E.M., 1971. The method for quantitative interpretation of gravitational and magnetic anomalies in the Yenisei-Khatanga trough. Geologiya i Geofizika (Russian Geology and Geophysics) (2), 25-30 (in Russian) [Казаис В.И., Яганцев Э.М. Методика количественной интерпретации гравитационных и магнитных аномалий в Енисей-Хатангском прогибе // Геология и геофизика. 1971. № 2. С. 25-30]. 
Khain V.E., 2001. Tectonics of Continents and Oceans (2000). Nauchny Mir, Moscow, 605 p. (in Russian) [Xauн B.E. Тектоника континентов и океанов (год 2000). М.: Научный мир, 2001. 605 с.].

Khain V.E., Lomize M.G., 1995. Geotectonics and Fundamentals of Geodynamics. MSU, Moscow, 480 p. (in Russian) [Хаин B.E., Ломизе М.Г. Геотектоника с основами геодинамики. М.: МГУ, 1995. 480 с.].

Kostyuchenko S.L., 2000. The crust structure and deep mechanisms in formation of the Near-Arctic continental sedimentary basins, Siberia. Regionalnaya Geologiya i Metallogeniya (Regional Geology and Metallogeny) (10), 125-135 (in Russian) [Костюченко С.Л. Структура коры и глубинные механизмы формирования приарктических континентальных осадочных бассейнов Сибири // Региональная геология и металлогения. 2000. № 10. C. 125-135].

Kushnir D.G., 2013. The efficiency of regional seismic surveys in Taimyr. Natural Resources of the Krasnoyarsk Region (18), 38-41 (in Russian) [Кушнир Д.Г. Эффективность региональных сейсморазведочных работ на Таймыре // Природные ресурсы Красноярского края. 2013. № 18. С. 38-41].

Kushnir D.G., 2016. Pre-Yenisei area of Taimyr and Gydan Peninsulas - deep seated geological structure and petroleum potential prospects. Neftegazovaya Geologiya. Teoriya i Praktika (Oil and Gas Geology. Theory and Practice) 11 (1), Article No. 6_2016 (in Russian) [Кушнир Д.Г. Глубинное геологическое строение и перспективы нефтегазоносности Приенисейской полосы Таймыра и Гыдана // Нефтегазовая геология. Теория и практика. 2016. T. 11. № 1. Статья № 6_2016]. https://doi.org/10.17353/2070-5379/6_2016.

Metelkin D.V., Kazansky A.Y., Vernikovsky V.A., Gee D., Torsvik T., 2000. First paleomagnetic data on the Early Paleozoic of the Severnaya Zemlya Archipelago and their geodynamic interpretation. Geologiya i Geofizika (Russian Geology and Geophysics) 41 (12), 1816-1820.

Metelkin D.V., Vernikovsky V.A., Kazansky A.Y., 2012. Tectonic evolution of the Siberian paleocontinent from the Neoproterozoic to the Late Mesozoic: paleomagnetic record and reconstructions. Russian Geology and Geophysics 53 (7), 675-688. https://doi.org/10.1016/j.rgg.2012.05.006.

Peskovsky I.D., 1992. The Evolution of the Lithosphere in West Siberia and Formation of the Sedimentary Basin. Nedra, Moscow, 334 p. (in Russian) [Песковский И.Д. Эволюция литосферы Западной Сибири и формирование осадочного бассейна. М.: Недра, 1992. 334 с.].

Smirnov Ya.B. (Ed.), 1980. The Heat Flow Map of the USSR and Adjacent Areas. Scale 1:10000000. Geological Institute of the USSR Acad. Sci., Main Department of Geodesy and Cartography for the USSR Council of Ministers, Moscow (in Russian) [Карта теплового потока территории СССР и сопредельных районов. Масштаб 1:10000000/ Ред. Я.Б. Смирнов. М.: Геологический институт АН СССР, Главное Управление геодезии и картографии при Совете Министров СССР, 1980].

Surkov V.S., 1998. Rifting and oil and gas basins of Siberia. Geologiya Nefti i Gaza (Oil and Gas Geology) (10), 33-36 (in Russian) [Сурков B.C. Рифтогенез и нефтегазоносные бассейны Сибири // Геология нефти и газа. 1998. № 10. C. 33-36].

Surkov V.S., Smirnov L.V., Zhero O.G., 1987. Early Mesozoic rifting and its influence on the lithosphere structure of the West Siberian plate. Geologiya i Geofizika (Russian Geology and Geophysics) (9), 3-11 (in Russian) [Cурков B.C., Смирнов Л.В., Жеро О.Г. Раннемезозойский рифтогенез и его влияние на структуру литосферы ЗападноСибирской плиты // Геология и геофизика. 1987. № 9. С. 3-11].

Vernikovsky V.A., 1996. Geodynamic Evolution of the Taimyr Folded Region. Publishing House of SB RAS, United Institute of Geology, Geophysics and Mineralogy, Novosibirsk, 202 p. (in Russian) [Верниковский В.А. Геодинамическая эволюция Таймырской складчатой области. Новосибирск: Изд-во СО РАН, НИЦ ОИГГМ, 1996. 202 с.].

Vernikovsky V.A., Kazansky A.Y., Matushkin N.Y., Metelkin D.V., Sovetov J.K., 2009. The geodynamic evolution of the folded framing and the western margin of the Siberian craton in the Neoproterozoic: geological, structural, sedimentological, geochronological, and paleomagnetic data. Russian Geology and Geophysics 50 (4), 380-393. https:// doi.org/10.1016/j.rgg.2009.03.014.

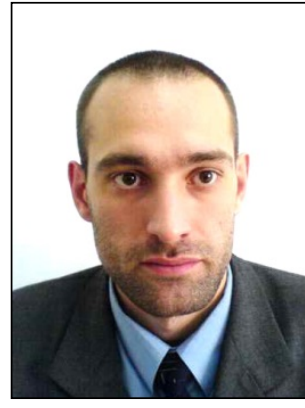

Денис Григорьевич Кушнир, канд. геол.-мин. наук

АО «Таймыргеофизика»

647000, Дудинка, ул. Рабочая, 42, Россия

e-mail: d.kushnir@tmrgeo.ru

Denis G. Kushnir, Candidate of Geology and Mineralogy

JSC "Taimyrgeofizika"

42 Rabochaya street, Dudinka 647000, Russia

$凶$ e-mail: d.kushnir@tmrgeo.ru 